\title{
Property Rights and Sustainable Natural Resource Management
}

\author{
Krishna Lal Poudel (Corresponding author) \\ Community Policy analysis Center (CPAC) \\ Department of Agricultural and Applied Economics, University of Missouri, Columbia, MO \\ E-mail: Klp7v3@mail.missouri.edu
}

Thomas G. Johnson

Professor Emeritus of Agricultural and Applied Economics

University of Missouri, Columbia, MO

E-mail: Johnsontg@ missouri.edu

Rachna Tewari

Assistant Professor, Agricultural Economics

Department of Agriculture, Geosciences, and Natural Resources

University of Tennessee at Martin, Martin, TN 38238

E-mail: rtewari@utm.edu

Received: April 13, 2016 Accepted: May 3, 2016

doi:10.5296/emsd.v5i2.9304 URL: http://dx.doi.org/10.5296/emsd.v5i2.9304

\begin{abstract}
This paper reviews recent research articles in the field of property rights and natural resources management, with the goal of identifying the most effective policy measures to achieve sustainable resource management through well designed property rights. Scarcity of economic resources is a major cause of conflict in human society. Institutions impact the resilience of the environment, and the institutions which guide humans as they employ resources from the environment are therefore essential to sustainable resource management.
\end{abstract}


Institutions which create and enforce property rights can control resource degradation and improve both economic and ecological efficiency. Property rights which lead to an equitable allocation of natural resources and delegation of management authority among stakeholders is the most likely pathway to sustainable ecosystem management. However, there is a lack of consensus regarding the best system of property rights to achieve sustainability. The 'best system' is contextual and spatiotemporal dynamic.

Keywords: Ecosystem, Forest, Institutions, Natura resource, Property Right

\section{Institutions, Decision Making and Wellbeing}

Society is comprised of diverse families with various preferences. Within a family, the individual is an important unit of analysis (Hodgson 2007; Udéhn 2002; Arrow 1994) according to methodological individualism. Given that the socio-economic structure is simply a function of formal and informal institutions that shape the evolution of societal governance mechanisms (North 1991), rational producers maximize profits and consumers maximize utility given competitive market mechanisms. Each individual's unique interests are reflected in his/her utility function. Sets of individual ordinal utility functions derived from management (production and consumption) of resources for everyone in society form the social welfare function (Just et al. 2004). This basic economic understanding is a vital requisite in designing an effective and efficient governance structure through organizational arrangements. One major concern is related to internalizing the externalities created by individual decisions regarding resource management and other economic activities.

Wealth maximizing individuals consider cooperation with other players when circumstances are repeated, when complete information is available about other players, and when there are a small number of players (North 1991; Olson 1971). Institutions are broadly defined as rules, habits, norms and values that shape the agent's actions and expectations (Heltberg 2002). Institutions serve management functions such as handling situations with missing information, explaining markets and market transactions, ensuring cooperation and collective action, and reducing transaction costs.

Natural resources are derived from the environment and often characterized by varying amounts of biodiversity and geo-diversity in various ecosystems (Schilling and Chiang 2011). Fundamentally, all manmade resources are composed of natural resources. Any increased or decreased demand for manmade products eventually exerts pressure to extract more or less natural resources respectively. These phenomena are happening at local, regional and trans-regional levels. Because individuals and communities are guided by their own utility functions, they act independently. Conflict arises when resources are characterized by rivalry and excludability. The scientific community has achieved consensus regarding variations in collective action behavior. Hardin (1968) and Olson (1971) recognize the possibility of dissonance between individuals regarding natural resources thus creating Prisoners' dilemmas and the tragedies of the commons. Ostrom (1990) argues that collective action problems justify nationalization or privatization of natural resources. It is also suggested that collective action can be problematic only when there is inadequate information, conflicting interests or when the nature of the resource itself leads to conflict (Poteete and Ostrom 2004). Two 
attributes, namely, i) lack of excludability and ii) non-rivalry of resource extraction characterize many natural resource systems (forests, watersheds, fisheries, etc.). The consequences of free riding and resource depletion impose heavy costs on society in the current as well as future time frames.

Individuals generally attribute less value to expected benefits in the distant future and more value to benefits in the immediate future. Uncertainties stemming from the lack of knowledge may be reduced over time through shared norms, collective performance, and scientific knowledge. There are always possibilities of opportunism and conditional cooperation. Long enduring collective action may solve fundamental problems in commonly held natural resource endowments. Ostrom (1990) developed eight design principles: defining resource boundary, congruence to rules and local conditions, collective choice arrangements, effective monitoring, graduated sanctions, low cost conflict resolution mechanisms, external recognition, and nested enterprises. Uncertainty, complexity, substantial biophysical constraints, and market forces reveal conflicting human values related to the management of environmental common pool resources (Dietz et al. 2003). The effectiveness of rules and norms in a specific time period, under a given socio-ecological-system, does not ensure that they will be effective in subsequent time periods. Rules and norms suggest strategies such as analytical deliberation, nesting institutional arrangements, and developing institutional variety to ensure more robust resource management in both time and space dimensions. Bhattarai and Hamming (2004) observed in their econometric analysis of the causes of deforestation that the variable for governance (combined indices for rule of law, quality of bureaucracy, and corruption level) was negative and statistically significant. The results from this study suggest that effective government plays an important role in controlling deforestation and hence enabling the conservation of tropical forest resources.

\section{Property Right and Resource Management}

Economic development strategies that are socially and environmentally sustainable have enjoyed growing interest (Serageldin 1996) in recent decades. Efficient and equitable distribution of resources for sustainable development depends on the ways property rights are defined and distributed (World Bank 1997). Wiebe and Meinzen-Dic (1998) argue that the nature and distribution of property rights are critical to how resources are used. Property rights are the formal and informal institutional arrangements for access and control over the resources and benefits generated thereby (Bromley 1997). Well defined property rights in a particular resource describe who can do what, and when and how they can do it with the resource. Public organizations play a key role in defining and enforcing property rights. According to Wiebe and Meinzen-Dic (1998), public agencies can play the following three important roles in shaping property rights:

1. Help establish the initial distribution of rights in resources within a community or society;

2. Influence the ways in which rights can be exchanged between the members of society; and

3. Describe how government itself may participate in the market for rights in resources. 
According to Allen (1991) property rights to a good must be defined, their use must be monitored, and possession of rights must be enforced. The costs of defining, monitoring, and enforcing property rights are referred to as transaction costs. Depending on the level of transaction costs, various forms of property rights institutions will develop. Each institutional form can be described by the distribution of rights. Property rights are an instrument of society and derive their significance from the fact that they help an individual form those expectations which he or she can reasonably hold in his or her dealings with others (Demsetz 1967). Property rights convey the right to benefit or harm oneself or others. The primary function of property rights is guiding incentives to achieve a greater internalization of externalities (Demsetz 1967). These expectations find expression in the laws, customs, and mores of a society. Property rights are reflected in the institutional set up and development. According to Demsetz (1988), emergence of property rights are because of marginal benefits (internalizing externalities) and marginal costs (defining and enforcing rights and responsibilities). Property right institutions are characterized with transaction costs. These costs result from the transfer of property rights and establishing and maintaining property rights (Allen 1991). A transaction cost explains both existence of the firm and existence of the law (Coase 1960).

Common and public resources ${ }^{1}$ are more vulnerable in terms of sustainable management. There is a range of appropriate property right regimes. Hardin (1968) argues that two state-established institutional arrangements - centralized government and private property - can work in the best pursuit of resources management. Bromley (1992) writes that natural resources can be managed as private, common or state property. Demsetz (1967) recommends establishing and strengthening private property rights as a policy strategy to reduce economic and managerial uncertainties. Private sector involvement in natural resource management is worthy because the private sector attempts to maximize its present value by taking into account the alternative future time streams of benefits and costs. If a resource does

\footnotetext{
1 In economics, private goods are excludable and rivalrous while public goods are both non-excludable and non-rivalrous (Varian, 1992). Non-rival means that one person's consumption of the good does not prevent another from consuming the good, and non-excludable means people cannot be prevented from consuming the good. Public goods are major sources of market failure (behavior of individual gain-seeking does not produce efficient outputs) and free rider problems (private cost exceeds private benefit and the incentive to provide the good or service through the market evaporates). Public good users care little about who else uses it since this does not affect the amount available to individuals. But since individuals cannot be excluded from using the resource they have an incentive to free-ride. Because of this, public goods are under-provided. Goods that are non-excludable, yet rival in consumption are known as commons, or common-pool resources. These goods are often a combination of natural or human-made resource systems (e.g. community forest, irrigation system or fishing floors). Size and/or characteristics of resources make exclusion costly, but not impossible. Because common resources are subtractable, they may face congestion or overuse, hence leading to the tragedy of commons. Rivers and lakes are available as an open access resource if and when there is an absence of enforced property rights (Ostrom et al., 1999). Non-consumptive attributes such as congestion may alter the nature of otherwise public resources.
} 
not provide economic value to human kind, it is hardly a resource in the economic sense and does not motivate individuals or groups of individuals to manage it. Binkley (1981) rigorously examined the harvest behavior of nonindustrial private forest landowners in the Northeastern United States. He found stumpage prices to be a significant predictor of harvest behavior. This suggests that the substitution effect of a price increase/decrease might be stronger/weaker than the income effect. This implies that provision of insurance and the development of carbon markets will be important future institutional arrangements to impact the decisions of nonindustrial private forest landowners (Amacher et al. 2003). Thus marketing integration is important for effective property rights and resource conservation in the future. Increased household income tends to bring improvements in socio-political institutions and allocation of environmental resources (Bhattarai and Hamming 2004). Individuals exhibit needs/preferences in a hierarchical order such as basic need through self-actualization. After fulfilling basic needs, individuals invest more in social capital and increase their demand for better environment and environment-friendly development.

Holling and Meffe (1996) argue that there is a pressing need of top-down command and control management to natural resources under increasing population and declining natural resource conditions. However, this approach has leads to problems of maintaining efficiency and sustainability in the long run, since it eventually leads to free riding and tragedy of the commons, and ultimately to a loss of system resilience. On the contrary, private ownership of land will internalize many of the external costs associated with communal ownership. For example, by virtue of their power to exclude others, one can increase the fertility of their land. The concentration of benefits and costs among owners creates incentives to utilize resources more efficiently (Wiebe and Meinzen-Dic 1998). They discuss property rights as policy tools for resource use and conservation with an examination of lessons from the United States' experience with 'partial interests' in land. "Partial Interest" in land involves the separation of property rights into several agreements among property owners leading to flexibility and varieties of resource management situations. Partial interest in land can involve potentially significant transaction costs. It exhibits a complicated relationship between multiple parties having different and conflicting objectives related to the parcel of land. For this reason, the concept of partial interest in land is difficult to apply in developing countries where property right institutions are weak or have not been yet been developed.

\section{Sustainable Resource Management}

Grumbine (1994) points out ten important themes of ecosystem management to reach sustainability. These are hierarchy context, ecological boundaries, biological integrity, data collection, monitoring, adaptive management, interagency cooperation, organizational change, humans embedded in nature, and values. These themes cover all aspects of ecosystem management and indicate the need for sustainable resource management in the present as well as the future. This study defines ecosystem management as "an integration of scientific knowledge of ecological relationships within a complex socio-political and values framework toward the general goal of protecting native ecosystem integrity over long term (pp: 31)."

The key issues concerning environmental resources are rivalry and excludability. If, for any 
reason, environmental resource loss exceeds growth/replenishment over a long period, an ecosystem is no longer sustainable. For example, sustainable forest management requires scale-wise solutions across geospatial units (Shifley 2006). Natural capital is one of the most important variables to the pursuit of livelihood (Scoones 1998). Sustainable livelihood means the ability to cope with and recover from shocks and stress, and maintain the system's capabilities and assets without depleting natural resources (Chamber and Conway 1991). Leopold (1949) argued that sustainability is the health of the ecosystem, and is of paramount importance: an environmental policy is right if it preserves the integrity of an ecosystem and wrong if it does not. Sustainable development is an interaction of the human, societal and environmental values in order to ensure sustained yield from the available natural resources without impeding future potential (Hall 2001). Barbier (2001) opined that agricultural development is a significant factor in deforestation. Deforestation causes the loss of biodiversity and other important components of the ecosystem. Tropical forests are more vulnerable to ecosystem loss through deforestation than forests in other ecosystems. Locatelli and Vignola (2009) find that water flows out of forested watersheds is significantly lower than non-forested watersheds. Ostrom (2007) writes regarding efficiency and sustainability of resource management for a wider coverage of socio-ecological systems (SES), stating that the cumulative capacities to diagnose the problems and potentialities of linked SESs require serious study of complex, multivariable, nonlinear, cross-scale, and changing systems. Ostrom also suggests that there is no single-policy panacea for crafting a sustainable ecosystem management system.

Ecosystem management is a leading approach in the forest sector (Dekker et al. 2007), however should work beyond the traditional resource management regimes (Grumbine 1994). Wiebe and Meinzen-Dic (1998) conclude that sustainable development requires more than market-led growth, and that there is a need for maintaining the environment and livelihood of all members of society. In general, the scientific community prefers a people centered participatory and bottom-up approach to managing natural resources in comparison to a top-down approach. However, there are many arguments for command and control strategies by government to protect endangered species and the environment. Private property rights should be limited in order to protect the environment (Jones et al. 1995). Trust should be created between both private and public stakeholders to establish an effective and sustainable resource management system (Raedeke et al. 2001; Creighton et al. 2002). Regardless of individual preferences, society as a whole benefits from a holistic approach to natural resource management (Creighton et al. 2002). Their research showed that educated and nonindustrial private forest landowners are interested in ecosystem-based management programs. Young and Reichenbach (1987) found that the intentions of individuals are more influenced by their own attitudes than by influence of social groups, while studying factors influencing timber harvest behavior of non-industrial private forest owners. This helps to transcend the boundaries of geography, administration and ownership (Grumbine 1994). 


\section{Relevant Case Studies}

\section{Case Study 1. Community Forestry in Nepal}

Traditionally the institutional design for community forest management in Nepal allowed open access. The local people had free entry and exit into the forest. Recently however, the government of Nepal has realized the importance of conserving natural resources by designing formal rules and regulations. The Forest Act of 1993 and Forest Regulations of 1995 provide a legal basis for community forestry in Nepal. The vision of the government is to encourage forest conservation and community development through group approaches. The groups are Community Forestry User Groups (CFUGs). In CFUGs, members make decisions regarding forest management, utilization and distribution of benefits. CFUGs act as self-governing local institutions to manage and utilize forests and other byproducts. Participatory forest management encourages local people to develop a resilient strategy for forest management. To date, 17,685 CFUGs have been organized and are managing $1,652,654$ ha of national forests which accounts for one-fourth of the total forest area of Nepal (GoN 2016). The local people are collectively managing community forestry activities for the production of collective goods. The collective goods are fire-wood, fodder, animal litter, non-timber forest products, thatching materials, and wild fruits.

A case study of a Community Forest Users Group in the eastern mid-hill region of Nepal concluded that, "group work to manage forest and associated watershed is a practical solution to address food security in the community". CFUG have recorded summer and winter season water increments leading to off-season vegetable production and increased on-farm net-income by about 55-60 percent. Their reliance on the forest for fodder and firewood has decreased by almost 90 percent. Interestingly, the deforested area inside the community forest has been fully covered with trees, shrubs, and some medicinal and aromatic plants species (Field Survey 2015; Focus Group Discussion 2015).

\section{Case Study 2. Cooperatives in Agroforestry}

The District Cooperative Federation of Gulmi in the western rural hill region of Nepal has been successful in producing organic coffee using an agroforestry model on the region's sloping and naked hills, and as a consequence, to improve the livelihood and food security of disadvantaged and marginal farm families. Degraded and deforested lands were brought under agroforestry practices in collective management in 2010. Within 4-5 years, the on-farm income increased by 80 percent and food insecurity decreased by about 40 percent among the small holders in the high altitude regions. Additionally, the livestock numbers increased by 35 percent because of increased fodder production (e.g. shade crops for coffee). Focus group discussions revealed that the region witnessed an increase in both biodiversity and water table levels, compared to the levels in the previous 5-7 years (Focus Group Discussion, 2015).

\section{Case Study 3. Community Managed Water Resources}

The Morangkhola Irrigation project, a public private partnership project, managed by a community water user group comprised of 21 members, was established to combat water resource shortfalls in the Dolkha District in Mountain region of Nepal. The project has been 
instrumental in increasing food security and environmental amenities in the region. The reservoir that is the source of water for the project is at an altitude of approximately 3,860 meters and the users are currently residing at 1,960 meters. This project supports 60 households by providing year-round irrigation and household drinking water supplies. The water user group not only manages the water springs to ensure the collection and storage of water, but it also employs a collective approach to protect the watershed's forest resources to ensure a long run supply of water for the region (Field Survey 2015; Focus Group Discussion 2015).

\section{Conclusion}

Rational actions to ensure sustainable resource management are ultimately governed by institutional capacity. Defining and enforcing property rights via effective institutional arrangements can provide solutions to economic problems such as the tragedy of the commons, resource depletion, resource encroachment, illegal trading, etc. There is no consensus around the debate whether state or private control is economically, socially and environmentally superior. Policies designed to address market failure and to promote public-private partnerships can improve all kinds of resource management situations. Based on the research literature and ground level studies, it can be concluded that sustainable resource management is possible through co-management. However, unless there are some provisions for economic incentives for stakeholders, it may be difficult to increase the adoption rates of sustainable resource management practices particularly in developing economies.

\section{Reference}

Allen, D. W. (1991). Homesteading and Property Rights; or, "How the West Was Really Won". Journal of Law and Economics, 34(1), 1-23. http://dx.doi.org/10.1086/467217

Allen, Douglas W. (1991). What are Transaction Costs? Research in Law and Economics, 14, 1-18. http://dx.doi.org/10.1086/467217

Amacher, G. S., Conway, C. M., \& J. Sullivan. (2003). Econometric Analyses of Nonindustrial Forest Landowners: Is There Anything Left to Study? Journal of Forest Economics, 9, 137-164. http://dx.doi.org/10.1078/1104-6899-00028

Arrow, Kenneth J. (1994). Methodological Individualism and Social Knowledge. American Economic Review, 84(2), 1-9.

Barbier, E. B., \& J. C. Burgess (2001). The Economics of Tropical Deforestation. Journal of Economic Surveys 15 (3), 413-421. http://dx.doi.org/10.1111/1467-6419.00144

Bhattarai, M., \& Hammig, M. (2004). Governance, Economic Policy, and the Environmental Kuznets Curve for Natural Tropical Forests. Environment and Development Economics, 9(3), 367-382. http://dx.doi.org/10.1017/S1355770X03001293

Binkley, C. S. (1981). Timber Supply from Private Nonindustrial Forests. Bulletin No. 92. New Haven, CT: Yale University School of Forestry and Environmental Studies. 
Bromley, D. (1992). The Commons, Common Property and Environmental Policy. Environmental and Resource Economics, 2(1), 1-17. http://dx.doi.org/10.1007/BF00324686

Bromley, D. W. (1997). Constitutional Political Economy: Property Claims in a Dynamic World. Contemporary Economic Policy, 15(4), 43-54. http://dx.doi.org/10.1111/j.1465-7287.1997.tb00488.x

Chambers, R., \& Conway, G. R. (1991). Sustainable Rural Livelihoods: Practical Concepts of the 21st Century. IDS. Discussion Paper Number 296.

Coase, Ronald H. (1960). The Problem of Social Cost. Journal of Law and Economics, 3, 1-44. http://dx.doi.org/10.1086/466560

Creighton, J., Baumgartner, D. M., \& K. Blatner. (2002). Ecosystem Management and Nonindustrial Private Forest Landowners in Washington State, USA. Small-scale Forest Economics, Management and Policy, 1(1), 55-69.

Dekker, M. E. Turnhout, B. M. S. D. L. Bauwens, \& G. M. J. Mohren. (2007). Interpretation and Implementation of Ecosystem Management in International and National Forest Policy. Forest Policy and Economics, 9, 546-557. http://dx.doi.org/10.1016/j.forpol.2006.03.003

Demsetz, H. (1967). Toward a Theory of Property Rights. The American Economic Review, 57(2), 347-359.

Demsetz, Harold. (1988). The Theory of the Firm Revisited. Journal of Law, Economics, and Organization, 4(1), 141-161.

Dietz, T., Ostrom, Elinor, \& P. Stern. (2003). The Struggle to Govern the Commons. Science, 302, 1907-1911. http://dx.doi.org/10.1126/science.1091015

GoN. (2016). Government of Nepal. Ministry of Forests and Soil Conservation. Department of Forests. Available at: http://dof.gov.np/dof_community_forest_division/community_forestry_dof\%20Adopted\%20 on\%20February\%2025

Grumbine, R. Edward. (1994). What Is Ecosystem Management? Conservation Biology, 8(1), 27-38. http://dx.doi.org/10.1046/j.1523-1739.1994.08010027.x

Hall, J. Peter. (2001). Criteria and Indicators of Sustainable Forest Management. Environmental Monitoring Assessment, 67(1-2), 109-119. http://dx.doi.org/10.1023/A:1006433132539

Hardin, G. (1968). The Tragedy of the Commons. Science, 162(3859), 1243-1248. http://dx.doi.org/10.1126/science.162.3859.1243

Heltberg, R. (2002). Property Rights and Natural Resource Management in Developing $\begin{array}{llllr}\text { Countries. Journal of Economic } & \text { Surveys, } 169(2), 214 .\end{array}$ http://dx.doi.org/10.1111/1467-6419.00164

Hodgson, G. (2007). Meaning of Methodological Individualism. Journal of Economic 
Methodology, 14(2), 211-26. http://dx.doi.org/10.1080/13501780701394094

Holling, C. S., \& G. K. Meffe. (1996). Command and Control and the Pathology of Natural

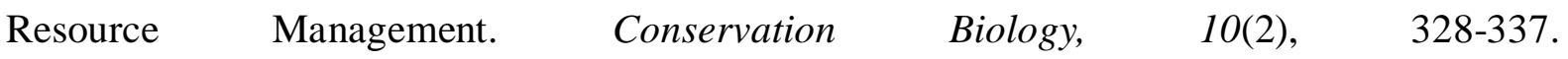
http://dx.doi.org/10.1046/j.1523-1739.1996.10020328.x

Jones, S. B., Luloff, A. E., \& Finley, J. C. (1995). Another Look at NTFP's: Facing Our Myths. Journal of Forestry, 93(9), 41-44.

Just, Richard E., Darell L. Hueth, \& Andrew Schmit. (2004). The Welfare Economics of Public Policy: A Practical Approach to Project and Policy Evaluation. Edward Elgar Publishing.

Leopold, A. (1949). A Sand County Almanac and Sketches Here and There. Oxford University Press. In: Kolstad, Charles D. 2000. Environmental Economics. Oxford University Press.

Locatelli B. and Raffaele Vignola. (2009). Managing Watershed Services of Tropical Forests and Plantations: Can Meta-analyses Help? Forest Ecology and Management. http://dx.doi.org/10.1016/j.foreco.2009.01.015

North, Douglass C. (1991). Institutions. The Journal of Economic Perspectives. 5(1), 97-112. http://dx.doi.org/10.1257/jep.5.1.97

Ostrom, E. (2007). A Diagnostic Approach for Going Beyond Panaceas. Proc. Natl. Acad. Science, 104(39), 15181-15187. http://dx.doi.org/10.1073/pnas.0702288104

Ostrom, E. (1990). Governing the Commons: The Evolution of Institutions for Collective Action. New York: Cambridge University Press. http://dx.doi.org/10.1017/CBO9780511807763

Ostrom, E.; Joanna, Burger; Christopher, B. Field; Richard, B. Norgaard \& David, Policansky. (1999). Revisiting the Commons: Local Lessons, Global Challenges. Science, 284(5412), 278-282. http://dx.doi.org/10.1126/science.284.5412.278

Poteete, A., \& E. Ostrom. (2004). In Pursuit of Comparable Concepts and Data about $\begin{array}{llll}\text { Collective Action. } & \text { Agricultural } & \text { Systems, } & \text { 82, }\end{array}$ http://dx.doi.org/10.1016/j.agsy.2004.07.002

Raedeke, A. H., Rikoon, J. S., \& Nilon, C. H. (2001). Ecosystem Management and Landowner Concern About Regulation: A Case Study in the Missouri Ozarks. Society and Natural Resources, 14, 741-759. http://dx.doi.org/10.1080/089419201753210576

Schilling, M., \& Chiang L. (2011). The Effect of Natural Resources on Sustainable Development policy: The Approach of Non-Sustainable Externalities. Energy Policy, 39, 990-998. http://dx.doi.org/10.1016/j.enpol.2010.11.030

Scoones, I. (1998). Sustainable Rural Livelihoods: A Framework Analysis. IDS working paper number 72, Cambridge. 


\section{Macrothink \\ Environmental Management and Sustainable Development \\ ISSN 2164-7682 \\ 2016, Vol. 5, No. 2}

Serageldin, I. (1996). Sustainable Development: From Theory to Practice. Finance and Development, 33(4).

Shifley, S. R. (2006). Sustainable Forestry in the Balance. Journal of Forestry 187-195.

Udéhn, L. (2002). The Changing Face of Methodological Individualism. Annual Review of Sociology, 28, 479-507. http://dx.doi.org/10.1146/annurev.soc.28.110601.140938

Varian, H. R. (1992). Microeconomic Analysis, 3rd Edition, W. W. Norton and Company, ISBN-13, 978-0393957358

Wiebe, K. D., \& R. Meinzen-Dick. (1998). Property Rights as Policy Tools for Sustainable Development. $\quad$ Land 203-215. http://dx.doi.org/10.1016/S0264-8377(98)00014-3

World Bank. (1997). Five Years After Rio: Innovations in Environmental Policy. Environmentally Sustainable Development Studies and Monographs Series No. 18.

Young, R., \& M. Reichenback. (1987). Factors Influencing the Timber Harvest Intentions of Nonindu strial Private Forest Owners. Forest Science, 33(2), 381-393.

\section{Copyright Disclaimer}

Copyright for this article is retained by the author(s), with first publication rights granted to the journal.

This is an open-access article distributed under the terms and conditions of the Creative Commons Attribution license (http://creativecommons.org/licenses/by/3.0/). 